\title{
Microsatellite Instability in Head and Neck Squamous Cell Carcinoma: A Study of a Brazilian Population
}

\author{
Elaine Stur, ${ }^{1}$ Eldamaria de Vargas Wolfgramm, ${ }^{1}$ Allan Kardec de Castro Neto, ${ }^{2}$ \\ Lucas de Lima Maia, ${ }^{1}$ Lidiane Pignaton Agostini, ${ }^{1}$ Gabriela Tonini Peterle, ${ }^{1}$ \\ Suzanny Oliveira Mendes, ${ }^{1}$ Marcelos dos Santos, ${ }^{1}$ \\ Flávia de Paula, ${ }^{1}$ and Iúri Drumond Louro ${ }^{1}$ \\ ${ }^{1}$ Núcleo de Genética Humana e Molecular, Departamento de Ciências Biológicas, Centro de Ciências Humanas e Naturais, \\ Universidade Federal do Espírito Santo, Avenida Marechal Campos, 1468, Maruípe, 29043-900 Vitória, ES, Brazil \\ ${ }^{2}$ Hospital Santa Rita de Cássia, Setor de Patologia, Vitória, ES, Brazil \\ Correspondence should be addressed to Iúri Drumond Louro; iurilouro@yahoo.com
}

Received 9 September 2013; Accepted 28 October 2013

Academic Editors: H.-L. Chan, A. Debucquoy, and M. Lotfy

Copyright (c) 2013 Elaine Stur et al. This is an open access article distributed under the Creative Commons Attribution License, which permits unrestricted use, distribution, and reproduction in any medium, provided the original work is properly cited.

Squamous cell carcinoma (SCC) is the sixth most common solid tumor in the world. Apart from known risk factors for head and neck SCC (HNSCC), there is a lack of information about genetic susceptibility regions that may play pivotal roles in the tumorigenesis of these tumors. Therefore, we have aimed to analyze the presence of genetic instability in microsatellite markers distributed in the genome. Microsatellite instability (MSI) was found in 6 HNSCC patients, among which only one was detected by the D17S250 marker, whereas the other 5 occurrences (13.5\%) were detected by the D3S1611 marker. No instability was found at markers D5S346, D10S197, D11S922, and D11S988. MSI detected by D3S1611 marker was present in 3 (14.3\%) moderately differentiated tumors and in $2(25.0 \%)$ poorly differentiated tumors, but no statistical significance was found. Genotypic frequencies for all markers showed no statistically significant distribution alteration, neither were they related to differentiation grade or patient age. Marker D3S1611 is located in the MLH1 gene, which is part of the mismatch repair system (MMR), helping to maintain genomic stability. We have found a higher rate of D3S1611 MSI in older patients, suggesting that this marker may be affected by aging processes in the DNA repair machinery.

\section{Introduction}

Head and neck cancer is a significant cause of mortality and morbidity worldwide, presenting approximately 600,000 new cases yearly [1], whereas tumors of the oral cavity contribute with 389,000 new cases per year, with a mortality rate of $50 \%$ [2]. Squamous cell carcinoma (SCC) is the most common histological variant, comprising $90 \%$ of all cases [3].

SCC is the sixth most common solid tumor in the world [4], found preferentially in 50-70-year-old individuals [5]. Nonetheless, some studies point towards a frequency shift towards younger ages, with several cases in men with less than 40 years of age [6].
The epidemiology of head and neck SCC (HNSCC) shows tobacco, alcohol, and Human Papilloma Virus (HPV) infection as the most important risk factors, as well as genetic susceptibility [7-11]. Therefore, the search for genetic markers has increased significantly over recent years.

Microsatellite regions are genomic $1-5 \mathrm{bp}$ tandem repeats, generally noncoding, and the CA $2 \mathrm{bp}$ repeat is the most common form [12]. These regions may present instability, especially caused by replication errors introduced by DNA polymerase, a phenomenon known as microsatellite instability (MSI) [13].

These replication mistakes may aid tumorigenesis through inactivation of tumor suppressor and repair genes, 
TABLE 1: Primers used for STR amplification.

\begin{tabular}{ll}
\hline Region & Sequence \\
\hline \multirow{2}{*}{ D3S1611 } & $5^{\prime}$-GCCGGGTACATTGGCCTGTAATC-3' \\
& $5^{\prime}$-AGCTGAGACTACAGGCATTTGCC-3' \\
& $5^{\prime}$-ACTCACTCTAGTGATAAATCGGG-3' \\
D5S346 & $5^{\prime}$-AGCAGATAAGACAGTATTACTAGTT-3' \\
& $5^{\prime}$-ACCACTGCACTTCAGGTGAC-3' \\
D10S197 & $5^{\prime}$-CTCAAGTGGCATTGTGAAATCTTCGAAC-3' \\
& $5^{\prime}$-GGGGCATCTTTGGCTACACTGG-3' \\
D11S922 & $5^{\prime}$-CTCTGACCGCCACCATGTATCC-3' \\
& $5^{\prime}$-CAGAAAATAGTTCAGACCACCA-3' \\
D11S988 & $5^{\prime}$-GGGACAAGAGAAAAGTTGAACA-3' \\
& $5^{\prime}$-GGAAGAATCAAATAGACAAT-3' \\
D17S250 & $5^{\prime}$-GCTGGCCATATATATATTTAAACC-3' \\
\hline
\end{tabular}

altering normal cell functions [12]. The fact that tumor cells harbor several genomic alterations and remarkable instability renders MSI markers a possible tool in the analysis of diverse tumor types. This study aimed to evaluate the MSI rate at six different genomic locations in HNSCC patients.

\section{Materials and Methods}

2.1. Samples. Samples were obtained from the Pathology Service of Santa Rita de Cássia Hospital (SRCH). Forty-two paraffin blocked HNSCC were analyzed (all from year 2009). Of all patients, 9 (21.4\%) were women and 33 (78.6\%) were men, with a mean age of 61 years ( $s d \pm 13.7)$. This study was approved by the Ethics Committee of the Federal University of Espírito Santo on 30/04/2009 (Protocol no. 010/09).

2.2. Genotyping. DNA was extracted according to Goelz et al. [14]. MSI at six different genomic locations was tested by polymerase chain reaction (PCR) in Eppendorf Mastercycler, using D3S1611, D5S346, D10S197, D11S922, D11S988, and D17S250 markers (primers described in Table 1). These regions were selected due to previous descriptions in the literature of genetic instability occurring at these markers in different tumor types [15]. Genomic region and reaction conditions are described in Table 2 . After amplification, PCR products were separated by vertical electrophoresis in $15 \%$ acrylamide gels and stained with $0.1 \%$ silver nitrate. Homozygozity or heterozygozity was characterized by the identification of one or two alleles in the normal tissue, respectively. Genetic instability was determined by the presence of different size bands or extra bands in the tumoral tissue, when compared to the normal tissue.

2.3. Statistical Analysis. The chi square and Fisher exact tests were used for association analysis and confirmation was obtained by the Lilliefors test (significance considered when
$P<0.05)$. Statistical calculations were performed using the Epi Info v3.4.3, 2007 software.

Samples that rendered unsuccessful amplification were excluded from the statistical analysis.

\section{Results}

MSI was found in 6 HNSCC patients, among which only 1 was detected by the D17S250 marker, whereas the other $5(13.5 \%)$ were detected by the D3S1611 marker. No instability was found at markers D5S346, D10S197, D11S922, and D11S988.

MSI detected by D3S1611 marker was more frequent in SCC of the oropharynx, but without a significant difference when compared to tumors of the mouth $(P=0.273)$ and larynx $(P=0.279)$. In relation to tumor differentiation, MSI detected by D3S1611 marker was present in $3(14.3 \%)$ moderately differentiated tumors and in 2 (25.0\%) poorly differentiated tumors, but no statistical significance was found $(P=0.339)$, probably due to the small sample size. Additionally, D3S1611 MSI was significantly associated with older age $(P=0.034$, Table 3$)$.

Genotypic frequencies for all markers showed no statistically significant distribution alteration, neither were they related to differentiation grade or patient age (Table 4).

\section{Discussion}

The present study has identified $13.5 \%$ MSI for samples analysed with D3S1611 marker. Our results are in agreement with Chakrabarti et al. [16], who identified even higher rates of MSI (40\%). In contrast, a lack of MSI in HNSCC was reported by other studies [16, 17]. These discrepancies may be explained by the great variability among repeat regions throughout the genome [18]. Instability frequency is related to the repeat unit length and overall size of the short tandem repeat (STR), affecting the probability of error during DNA replication [19, 20]. Furthermore, individuals from diverse geographic locations may present differences in their STR characteristics [21], possibly affecting accuracy during replication. Therefore, it is possible that populations with a longer average repeat size are more prone to instability than the ones with a smaller repeat size.

Marker D3S1611 is located in the MLH1 gene (mutL homolog 1), coding for an enzyme responsible for aiding in the mismatch repair system (MMR), which is pivotal for the maintenance of genomic stability, repairing DNA heteroduplexes generated by replication [22, 23]. MLH1 gene alterations are related to the development of colorectal cancer, suggesting that this enzyme is needed for correct DNA repair at least in some tissues [21].

In addition, we have found a higher rate of D3S1611 MSI in older patients, suggesting that this marker may be affected by aging processes in the DNA repair machinery. According to Hardwick et al. repeat size expansion is an inevitable 
TABLE 2: Genomic characteristics and reaction conditions for MSI markers.

\begin{tabular}{|c|c|c|c|c|c|c|}
\hline \multirow{2}{*}{ Characteristics } & \multicolumn{6}{|c|}{ MSI marker } \\
\hline & D3S1611 & D5S346 & D10S197 & D11S922 & D11S988 & D17S250 \\
\hline \multicolumn{7}{|l|}{ Genomic } \\
\hline Chromosomal location & $3 p 21.3$ & $5 q 21$ & $10 \mathrm{p} 12$ & $11 \mathrm{p} 15.5$ & $11 \mathrm{p} 15.5$ & $17 q 11.2$ \\
\hline STR sequence & $(\mathrm{CA})_{n}$ & $(\mathrm{CA})_{n}$ & $(\mathrm{CA})_{n}$ & $(\mathrm{CA})_{n}$ & $(\mathrm{CA})_{n}$ & $(\mathrm{CA})_{n}$ \\
\hline Fragment size & $140 \mathrm{pb}$ & $115 \mathrm{pb}$ & $141 \mathrm{pb}$ & $175 \mathrm{pb}$ & $120 \mathrm{pb}$ & $151 \mathrm{pb}$ \\
\hline \multicolumn{7}{|l|}{ Reaction conditions } \\
\hline Platinum taq DNA polymerase & $0.2 \mathrm{u}$ & $0.2 \mathrm{u}$ & $0.2 \mathrm{u}$ & $0.2 \mathrm{u}$ & $0.2 \mathrm{u}$ & $0.2 \mathrm{u}$ \\
\hline $25 \mu \mathrm{M}$ primers $\mathrm{F} / \mathrm{R}$ & $0.3 \mu \mathrm{L}$ & $0.6 \mu \mathrm{L}$ & $0.6 \mu \mathrm{L}$ & $0.6 \mu \mathrm{L}$ & $0.6 \mu \mathrm{L}$ & $0.6 \mu \mathrm{L}$ \\
\hline $10 \mathrm{mM}$ dNTP & $0.2 \mathrm{mM}$ & $0.2 \mathrm{mM}$ & $0.2 \mathrm{mM}$ & $0.2 \mathrm{mM}$ & $0.2 \mathrm{mM}$ & $0.2 \mathrm{mM}$ \\
\hline $50 \mathrm{mM} \mathrm{MgCl}_{2}$ & $1.5 \mathrm{mM}$ & $1.5 \mathrm{mM}$ & $1.5 \mathrm{mM}$ & $1.5 \mathrm{mM}$ & $1.5 \mathrm{mM}$ & $1.5 \mathrm{mM}$ \\
\hline 10X PCR buffer & $1 \mathrm{X}$ & $1 \mathrm{X}$ & $1 \mathrm{X}$ & $1 \mathrm{X}$ & $1 \mathrm{X}$ & $1 \mathrm{X}$ \\
\hline DMSO 100\% & & $0.75 \mu \mathrm{L}$ & & & & \\
\hline DNA & $1.2 \mu \mathrm{L}$ & $1.2 \mu \mathrm{L}$ & $0.6 \mu \mathrm{L}$ & $1.8 \mu \mathrm{L}$ & $1 \mu \mathrm{L}$ & $0.6 \mu \mathrm{L}$ \\
\hline Final volume & $15 \mu \mathrm{L}$ & $15 \mu \mathrm{L}$ & $15 \mu \mathrm{L}$ & $15 \mu \mathrm{L}$ & $15 \mu \mathrm{L}$ & $15 \mu \mathrm{L}$ \\
\hline \multicolumn{7}{|l|}{ Cycling conditions } \\
\hline Number of cycles & 30 & 30 & 28 & 30 & 32 & 30 \\
\hline Annealing & $70^{\circ} \mathrm{C}$ for $15 \mathrm{seg}$ & $55^{\circ} \mathrm{C} ; 30$ seg & $70^{\circ} \mathrm{C} ; 30 \mathrm{seg}$ & $68^{\circ} \mathrm{C} ; 30$ seg & $69^{\circ} \mathrm{C} ; 30 \mathrm{seg}$ & $50^{\circ} \mathrm{C} ; 30 \mathrm{seg}$ \\
\hline
\end{tabular}

TABLE 3: D3S1611 MSI frequency according to clinical and epidemiological features.

\begin{tabular}{|c|c|c|c|c|c|c|c|}
\hline \multirow{3}{*}{ Features } & \multicolumn{7}{|c|}{ D3S1611 marker } \\
\hline & \multicolumn{2}{|c|}{ Total } & \multicolumn{2}{|c|}{ MSI } & \multicolumn{2}{|c|}{ MSS } & \multirow{2}{*}{$P$} \\
\hline & No. & $(\%)$ & No. & $f$ & No. & $f$ & \\
\hline \multicolumn{8}{|l|}{ Gender } \\
\hline Female & 8 & $(21.6)$ & 1 & 0.125 & 7 & 0.875 & - \\
\hline Male & 29 & $(78.4)$ & 4 & 0.138 & 25 & 0.862 & \\
\hline \multicolumn{8}{|l|}{ Age range, yrs } \\
\hline$\leq 50$ & 8 & $(21.6)$ & 0 & 0.0 & 8 & 1.0 & 0.034 \\
\hline $50-70$ & 22 & $(59.5)$ & 2 & 0.091 & 20 & 0.909 & \\
\hline$>70$ & 7 & $(18.9)$ & 3 & 0.492 & 4 & 0.508 & \\
\hline \multicolumn{8}{|l|}{ Tumor site } \\
\hline Oral cavity & 15 & $(40.5)$ & 1 & 0.067 & 14 & 0.933 & - \\
\hline Oropharynx & 8 & $(21.6)$ & 3 & 0.375 & 5 & 0.625 & \\
\hline Larynx & 14 & $(37.9)$ & 1 & 0.071 & 13 & 0.929 & \\
\hline \multicolumn{8}{|l|}{ Differentiation } \\
\hline Well & 8 & $(21.6)$ & 0 & 0.0 & 8 & 1.0 & 0.339 \\
\hline Moderately & 21 & $(56.8)$ & 3 & 0.143 & 18 & 0.857 & \\
\hline Poorly & 8 & $(21.6)$ & 2 & 0.250 & 6 & 0.750 & \\
\hline Total & 37 & $(100.0)$ & 5 & 0.135 & 32 & 0.865 & \\
\hline
\end{tabular}

MSI: microsatellite instability; MSS: microsatellite stable; $f$ : frequency; $P$ : significance value.

and progressive phenomenon along the life span of rodents [24].

In conclusion, the present study reports that D3S1611 marker can identify instability in a fraction of HNSCC patients, being related to older ages.

\section{Ethical Approval}

This study was approved by the Ethics Committee of the Federal University of Espírito Santo on 30/04/2009 (Protocol no. 010/09). 
TABLE 4: Marker genotypic frequencies, according to clinical and epidemiological features.

\begin{tabular}{|c|c|c|c|c|c|c|c|c|c|c|c|c|c|c|c|}
\hline \multirow{3}{*}{ Features } & \multicolumn{15}{|c|}{ Genotypic frequencies } \\
\hline & \multicolumn{4}{|c|}{ D3S1611 } & \multirow{2}{*}{$P$} & \multicolumn{4}{|c|}{ D5S346 } & \multirow{2}{*}{$P$} & \multicolumn{4}{|c|}{ D10S197 } & \multirow{2}{*}{$P$} \\
\hline & HT & $f$ & $\mathrm{HM}$ & $f$ & & HT & $f$ & HM & $f$ & & $\mathrm{HT}$ & $f$ & $\mathrm{HM}$ & $f$ & \\
\hline Total & 26 & 0.703 & 11 & 0.297 & - & 23 & 0.821 & 5 & 0.179 & - & 29 & 0.879 & 4 & 0.121 & - \\
\hline \multicolumn{16}{|l|}{ Gender } \\
\hline Female & 6 & 0.750 & 2 & 0.250 & \multirow[t]{2}{*}{-} & 7 & 0.875 & 1 & 0.125 & \multirow[t]{2}{*}{ - } & 8 & 1.0 & 0 & 0.0 & \multirow[t]{2}{*}{-} \\
\hline Male & 20 & 0.690 & 9 & 0.310 & & 16 & 0.800 & 4 & 0.200 & & 21 & 0.840 & 4 & 0.160 & \\
\hline \multicolumn{16}{|l|}{ Age range, yrs } \\
\hline$\leq 50$ & 7 & 0.875 & 1 & 0.125 & \multirow[t]{3}{*}{0.448} & 5 & 1.0 & 0 & 0.0 & \multirow[t]{3}{*}{0.513} & 6 & 1.0 & 0 & 0.0 & \multirow[t]{3}{*}{0.58} \\
\hline $50-70$ & 14 & 0.636 & 8 & 0.364 & & 14 & 0.778 & 4 & 0.222 & & 16 & 0.842 & 3 & 0.158 & \\
\hline$>70$ & 5 & 0.714 & 2 & 0.286 & & 4 & 0.800 & 1 & 0.200 & & 7 & 0.875 & 1 & 0.125 & \\
\hline \multicolumn{16}{|l|}{ Tumor site } \\
\hline Oral cavity & 9 & 0.600 & 6 & 0.400 & \multirow[t]{3}{*}{-} & 11 & 0.786 & 3 & 0.214 & \multirow[t]{3}{*}{ - } & 12 & 0.857 & 2 & 0.143 & \multirow[t]{3}{*}{-} \\
\hline Oropharynx & 6 & 0.750 & 2 & 0.250 & & 6 & 1.0 & 0 & 0.0 & & 7 & 0.875 & 1 & 0.125 & \\
\hline Larynx & 11 & 0.786 & 3 & 0.214 & & 6 & 0.750 & 2 & 0.250 & & 10 & 0.909 & 1 & 0.091 & \\
\hline \multicolumn{16}{|l|}{ Differentiation } \\
\hline Well & 8 & 1.0 & 0 & 0.0 & \multirow[t]{3}{*}{0.115} & 7 & 1.0 & 0 & 0.0 & 0.334 & 7 & 1.0 & 0 & 0.0 & 0.518 \\
\hline Moderately & 13 & 0.619 & 8 & 0.381 & & 11 & 0.786 & 3 & 0.214 & & 15 & 0.833 & 3 & 0.167 & \\
\hline Poorly & 5 & 0.625 & 3 & 0.375 & & 5 & 0.714 & 2 & 0.286 & & 7 & 0.875 & 1 & 0.125 & \\
\hline & & & & & & & Geno & pic fr & uencies & & & & & & \\
\hline Features & & & $\$ 922$ & & $P$ & & D1 & 988 & & $P$ & & $\mathrm{D} 1$ & 250 & & $P$ \\
\hline & HT & $f$ & $\mathrm{HM}$ & $f$ & & HT & $f$ & HM & $f$ & & $\mathrm{HT}$ & $f$ & $\mathrm{HM}$ & $f$ & \\
\hline Total & 19 & 0.760 & 6 & 0.240 & - & 26 & 0.867 & 4 & 0.133 & - & 28 & 0.875 & 4 & 0.125 & - \\
\hline Gender & & & & & & & & & & & & & & & \\
\hline Female & 7 & 0.875 & 1 & 0.125 & - & 8 & 1.0 & 0 & 0.0 & - & 7 & 0.875 & 1 & 0.125 & - \\
\hline Male & 12 & 0.706 & 5 & 0.294 & & 18 & 0.818 & 4 & 0.182 & & 21 & 0.875 & 3 & 0.125 & \\
\hline Age range, yrs & & & & & & & & & & & & & & & \\
\hline$\leq 50$ & 4 & 0.800 & 1 & 0.200 & 0.413 & 5 & 1.0 & 0 & 0.0 & 0.171 & 5 & 0.833 & 1 & 0.167 & 0.912 \\
\hline $50-70$ & 11 & 0.688 & 5 & 0.313 & & 13 & 0.765 & 4 & 0.235 & & 17 & 0.895 & 2 & 0.105 & \\
\hline$>70$ & 4 & 1.0 & 0 & 0.0 & & 8 & 1.0 & 0 & 0.0 & & 6 & 0.857 & 1 & 0.143 & \\
\hline Tumor site & & & & & & & & & & & & & & & \\
\hline Oral cavity & 9 & 0.692 & 4 & 0.308 & - & 11 & 0.917 & 1 & 0.083 & - & 12 & 0.923 & 1 & 0.077 & - \\
\hline Oropharynx & 6 & 1.0 & 0 & 0.0 & & 7 & 0.875 & 1 & 0.125 & & 8 & 1.0 & 0 & 0.0 & \\
\hline Larynx & 4 & 0.667 & 2 & 0.333 & & 8 & 0.800 & 2 & 0.200 & & 8 & 0.727 & 3 & 0.273 & \\
\hline Differentiation & & & & & & & & & & & & & & & \\
\hline Well & 6 & 0.857 & 1 & 0.143 & 0.586 & 7 & 1.0 & 0 & 0.0 & 0.436 & 6 & 0.857 & 1 & 0.143 & 0.986 \\
\hline Moderately & 10 & 0.769 & 3 & 0.231 & & 12 & 0.800 & 3 & 0.200 & & 15 & 0.882 & 2 & 0.118 & \\
\hline Poorly & 3 & 0.600 & 2 & 0.400 & & 7 & 0.875 & 1 & 0.125 & & 7 & 0.875 & 1 & 0.125 & \\
\hline
\end{tabular}

HT: heterozygote; HM: homozygote; $f$ : frequency; $P$ : significance value.

\section{Conflict of Interests}

The authors declare that they have no competing interests.

\section{Acknowledgments}

Part of this study was sponsored by Fibria Celulose, Fundação de Amparo a Pesquisa do Espírito Santo (FAPES), and Coordenação de Aperfeiçoamento de Pessoal de Nível Superior (Capes) scholarships. The authors thank the Hospital Santa Rita de Cássia for providing the biological samples.

\section{References}

[1] J. E. Bauman, L. S. Michel, and C. H. Chung, "New promising molecular targets in head and neck squamous cell carcinoma," Current Opinion in Oncology, vol. 24, no. 3, pp. 235-242, 2012.

[2] J. Ferlay, H. R. Shin, F. Bray et al., "GLOBOCAN 2008, cancer incidence and mortality worldwide," in IARC CancerBase No. 10, International Agency for Research on Cancer, 2010, http://globocan.iarc.fr.

[3] M. L. Gillison, "Current topics in the epidemiology of oral cavity and oropharyngeal cancers," Head and Neck, vol. 29, no. 8, pp. 779-792, 2007. 
[4] H. De Schutter, M. Spaepen, W. H. Mc Bride, and S. Nuyts, "The clinical relevance of microsatellite alterations in head and neck squamous cell carcinoma: a critical review," European Journal of Human Genetics, vol. 15, no. 7, pp. 734-741, 2007.

[5] I. J. Hoogsteen, H. A. M. Marres, J. Bussink, A. J. Van Der Kogel, and J. H. A. M. Kaanders, "Tumor microenvironment in head and neck squamous cell carcinomas: predictive value and clinical relevance of hypoxic markers. A review," Head and Neck, vol. 29, no. 6, pp. 591-604, 2007.

[6] S. Marur and A. A. Forastiere, "Head and neck cancer: changing epidemiology, diagnosis, and treatment," Mayo Clinic Proceedings, vol. 83, no. 4, pp. 489-501, 2008.

[7] J. Colombo and P. Rahal, "Genética de cancer de cabeça e pescoço," Revista da Sociedade Brasileira de Cancerologia, vol. 55, pp. 165-174, 2009.

[8] R. H. Brakenhoff, "Another NOTCH for cancer," Science, vol. 333, article 1102, 2011.

[9] S. Han, Y. Chen, X. Ge et al., "Epidemiology and cost analysis for patients with oral cancer in a university hospital in China," BMC Public Health, vol. 10, article 196, 2010.

[10] L. D. M. Alvarenga, M. T. Ruiz, É. C. Pavarino-Bertelli, M. J. C. Ruback, J. V. Maniglia, and E. M. Goloni-Bertollo, "Epidemiologic evaluation of head and neck patients in a university hospital of Northwestern São Paulo State," Brazilian Journal of Otorhinolaryngology, vol. 74, no. 1, pp. 68-73, 2008.

[11] R. A. Dedivitis, C. M. França, A. C. B. Mafra, F. T. Guimarães, and A. V. Guimarães, "Clinic and epidemiologic characteristics in the with squamous cell carcinoma of the mouth and oropharynx," Revista Brasileira de Otorrinolaringologia, vol. 70, no. 1, pp. 35-40, 2004.

[12] H. Arabi, H. Guan, S. Kumar et al., "Impact of microsatellite instability (MSI) on survival in high grade endometrial carcinoma," Gynecologic Oncology, vol. 113, no. 2, pp. 153-158, 2009.

[13] J. G. Martínez, J. Pérez-Escuredo, F. López et al., "Microsatellite instability analysis of sinonasal carcinomas," OtolaryngologyHead and Neck Surgery, vol. 140, pp. 55-60, 2009.

[14] S. E. Goelz, S. R. Hamilton, and B. Vogelstein, "Purification of DNA from formaldehyde fixed and paraffin embedded human tissue," Biochemical and Biophysical Research Communications, vol. 130, no. 1, pp. 118-126, 1985.

[15] E. V. Wolfgramm, L. N. R. Alves, E. Stur et al., "Analisys of genome instability in breast cancer," Molecular Biology Reports, vol. 40, pp. 2139-2144, 2013.

[16] S. Chakrabarti, S. Dasgupta, S. Roy et al., "Microsatellite instability in squamous cell carcinoma of head and neck from the Indian patient population," International Journal of Cancer, vol. 92, no. 4, pp. 555-561, 2001.

[17] M. M. Sasiadek, A. Stembalska-Kozlowska, R. Smigiel, D. Ramsey, T. Kayademir, and N. Blin, "Impairment of MLHI and CDKN2A in oncogenesis of laryngeal cancer," British Journal of Cancer, vol. 90, no. 8, pp. 1594-1599, 2004.

[18] H. de Schutter, M. Spaepen, S. Van Opstal, V. Vander Poorten, E. Verbeken, and S. Nuyts, "The prevalence of microsatellite instability in head and neck squamous cell carcinoma," Journal of Cancer Research and Clinical Oncology, vol. 135, no. 3, pp. 485-490, 2009.

[19] V. A. Stepanov, M. G. Spiridonova, V. N. Tadinova et al., "Analysis of genetic diversity of population of Northern Eurasia from autosomal microsatellite loci," Genetika, vol. 39, pp. 13811388, 2003.
[20] A. Mukherjee, T. J. McGarrity, F. Ruggiero et al., “The revised Bethesda guidelines: extent of utilization in a university hospital medical center with a cancer genetics program," Hereditary Cancer in Clinical Practice, vol. 8, no. 1, article 9, 2010.

[21] Z. Yalniz, S. Demokan, Y. Suoglu, M. Ulusan, and N. Dalay, "Assessment of microsatellite instability in head and neck cancer using consensus markers," Molecular Biology Reports, vol. 37, no. 7, pp. 3541-3545, 2010.

[22] M. Mrkonjic, N. M. Roslin, C. M. Greenwood et al., "Specific variants in the MLH1 gene region may drive DNA methylation, loss of protein expression, and MSI-H colorectal cancer," PLoS ONE, vol. 5, no. 10, Article ID el3314, 2010.

[23] Q. Wu and K. M. Vasquez, "Human MLH1 protein participates in genomic damage checkpoint signaling in response to DNA interstrand crosslinks, while MSH2 functions in DNA repair," PLoS Genetics, vol. 4, no. 9, Article ID e1000189, 2008.

[24] R. J. Hardwick, M. V. Tretyakov, and Y. E. Dubrova, "Age-related accumulation of mutations supports a replication-dependent mechanism of spontaneous mutation at tandem repeat DNA loci in mice," Molecular Biology and Evolution, vol. 26, no. 11, pp. 2647-2654, 2009. 


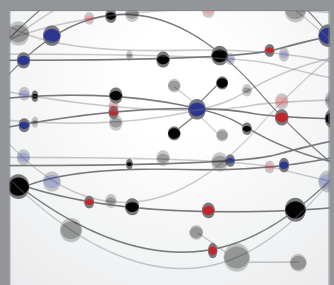

The Scientific World Journal
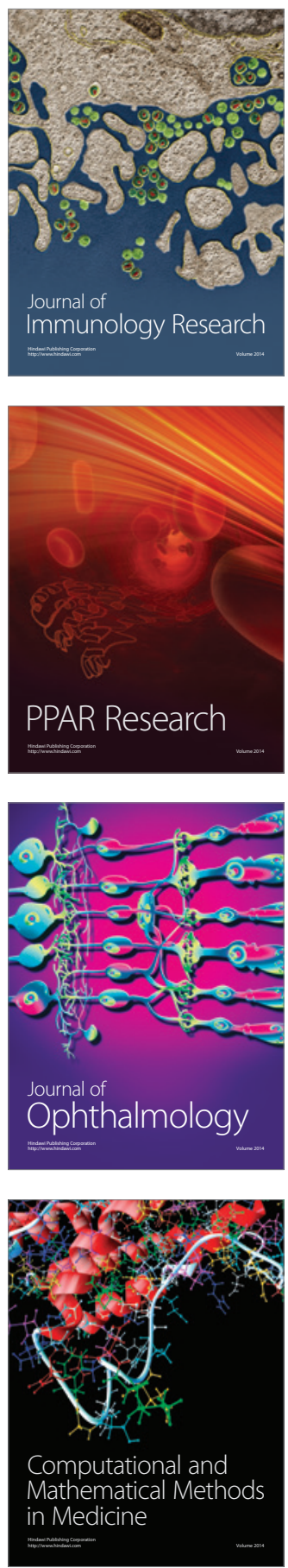

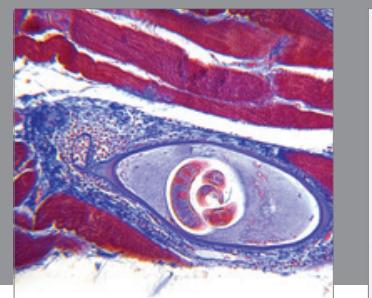

Gastroenterology

Research and Practice
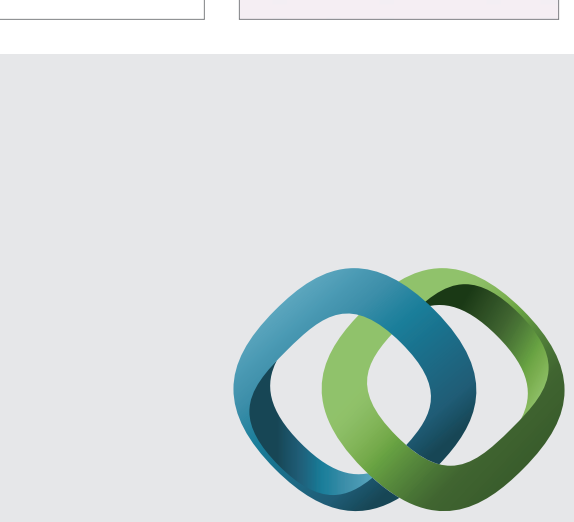

\section{Hindawi}

Submit your manuscripts at

http://www.hindawi.com
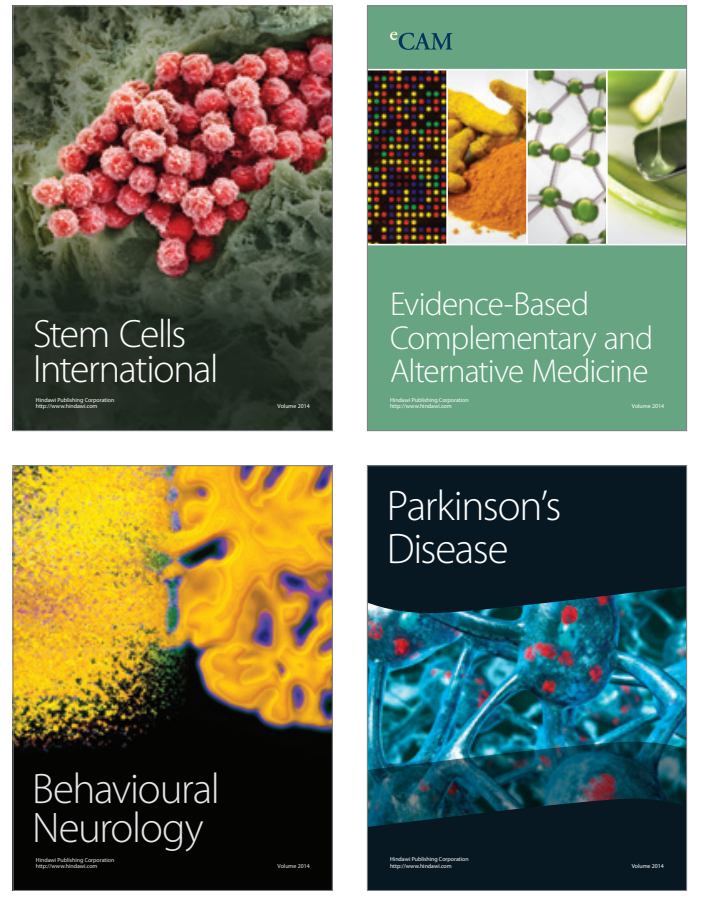
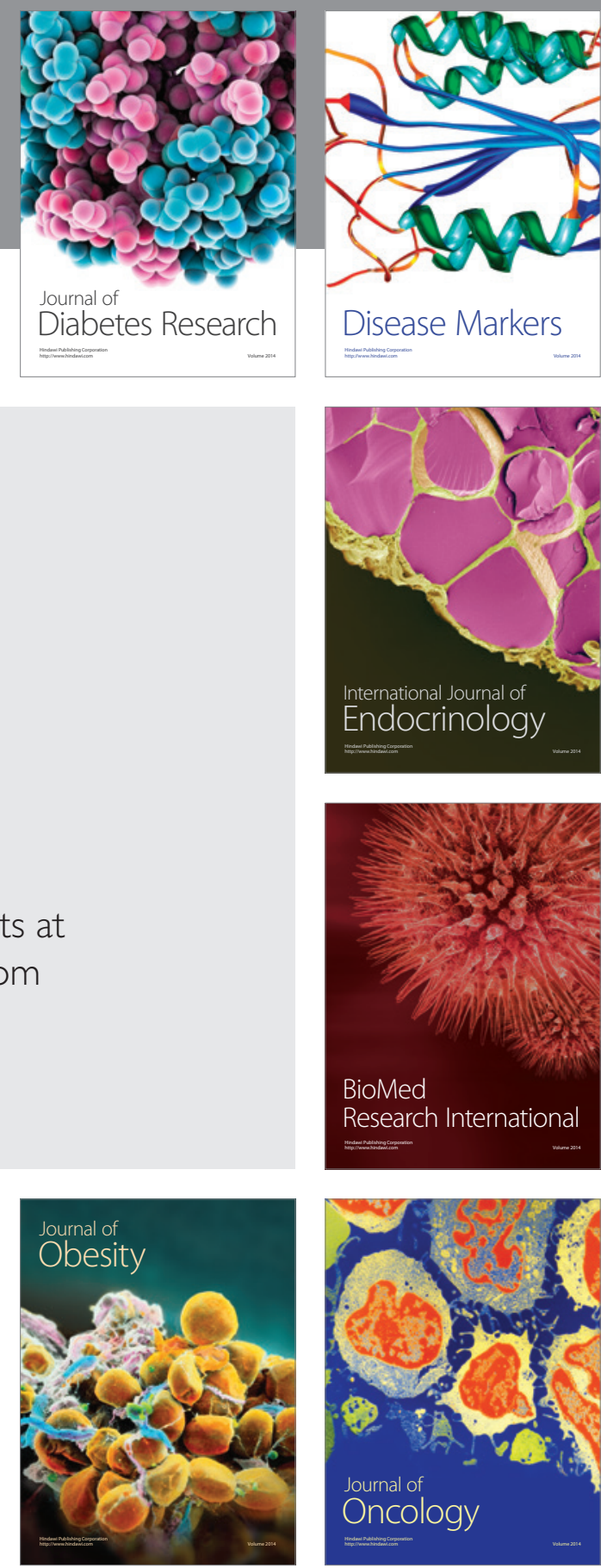

Disease Markers
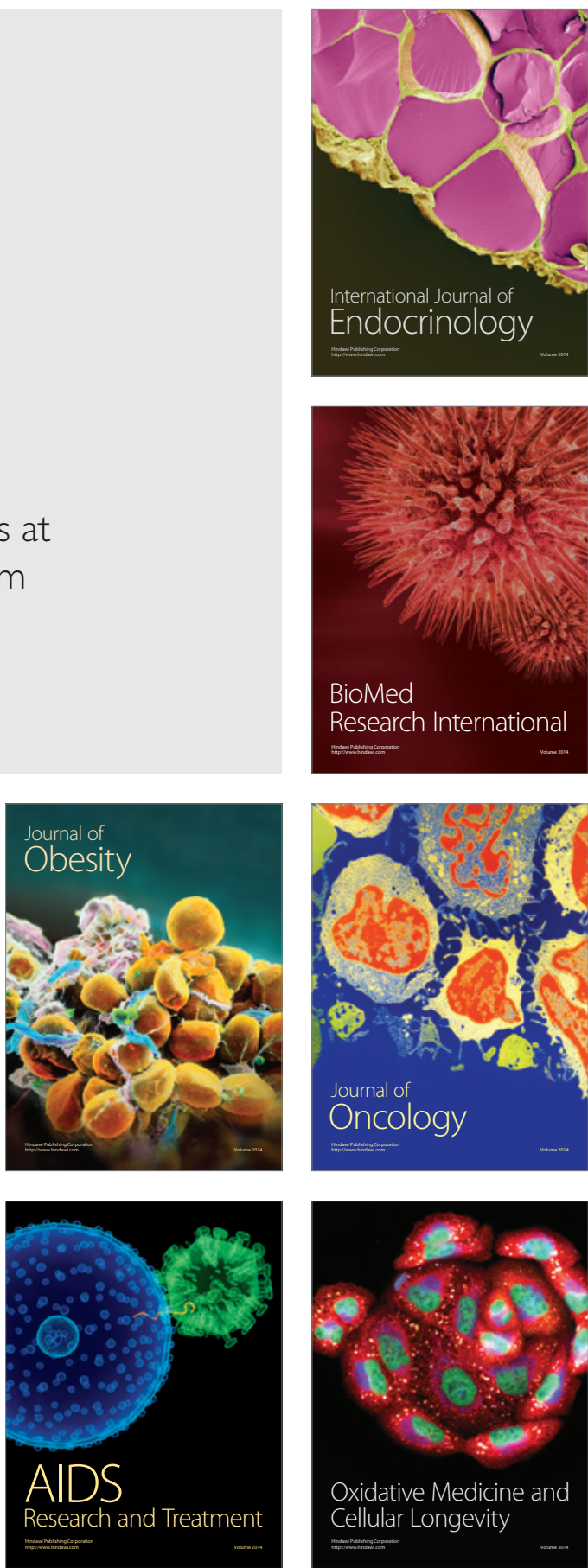